\title{
Influence of FYM and irrigation frequency on yield, vitamin and mineral contents of organic cabbage (Brassica oleracea var. capitata)
}

\author{
AJEET KUMAR, AJAY KUMAR RAI AND NIRMAL DE
}

Received : 26.05.2015; Revised : 11.10.2015; Accepted : 25.10 .2015

\author{
MEMBERS OF RESEARCH FORUM: \\ Corresponding author : \\ NIRMAL DE, Department of Soil \\ Science and Agricultural Chemistry, \\ Institute of Agricultural Science, \\ Banaras Hindu University, VARANASI \\ (U.P.) INDIA \\ Email : nirmalde@gmail.com
}

Co-authors :

AJAY KUMAR RAI, Krishi Vigyan Kendra (CIAH), PANCHMAHAL (GUJARAT) INDIA

AJEET KUMAR, Department of Soil Science and Agricultural Chemistry, Regional Research Station, Madhopur, WEST CHAMPARAN (BIHAR) INDIA

\section{Summary}

A field experiment to assess the effect of organic fertilizers on the growth and yield of cabbage was conducted at the Research farm of Indian Institute of Vegetable Research, Varanasi (U.P.). A Randomized Block Design with four level of FYM replicated three times was used in the experiment. Neem seed kernel extract (NSKE) 4 per cent was sprayed at the advent of insect pest infestation. In addition to marketable yields, cabbage leaves were digested and analyzed for 11 macro- and micronutrients. Vitamins $\mathrm{C}$ and $\mathrm{E}$ of mature crops were evaluated by high performance liquid chromatography. Soil samples were also taken at harvest, extracted with suitable extractant solution and analyzed for essential nutrients. Application of different level of FYM had varying effects on the growth and yield of cabbage. Effect of FYM was better in both the cabbage variety with respect to their variables measured, i.e. height, marketable head weight, and yield per ha. These findings can be explained in terms of the availability, especially, of the macro-nutrients in each of the treated plots. The impact of irrigation frequency on yield is transparent. We conclude that irrigation frequency had a significant bearing on yield.

Key words : Organic, Cabbage, Farm yard manure, Growth, Irrigation frequency, Yield, Vitamins

How to cite this article : Kumar, Ajeet, Rai, Ajay Kumar and De, Nirmal (2015). Influence of FYM and irrigation frequency on yield, vitamin and mineral contents of organic cabbage (Brassica oleracea var. capitata). Asian J. Soil Sci., 10(2) : 215-221. 